\title{
ADENOSINE DEAMINASE ACTIVITY AND SERUM C-REACTIVE PROTEIN AS PROGNOSTIC MARKERS OF CHAGAS DISEASE SEVERITY
}

\author{
Iván Darío BRAVO-TOBAR(1), Carlota NELLO-PÉREZ(1), Alí FERNÁNDEZ(2), Nora MOGOLLÓN(1), Mary Carmen PÉREZ(1), \\ Juan VERDE(3), Juan Luis CONCEPCIÓN(4), Claudina RODRIGUEZ-BONFANTE(3) \& Rafael BONFANTE-CABARCAS(1)
}

\begin{abstract}
SUMMARY
Chagas disease is a public health problem worldwide. The availability of diagnostic tools to predict the development of chronic Chagas cardiomyopathy is crucial to reduce morbidity and mortality. Here we analyze the prognostic value of adenosine deaminase serum activity (ADA) and C-reactive protein serum levels (CRP) in chagasic individuals. One hundred and ten individuals, 28 healthy and 82 chagasic patients were divided according to disease severity in phase I $(n=35)$, II $(n=29)$, and III $(n=18)$. A complete medical history, 12-lead electrocardiogram, chest X-ray, and M-mode echocardiogram were performed on each individual. Diagnosis of Chagas disease was confirmed by ELISA and MABA using recombinant antigens; ADA was determined spectrophotometrically and CRP by ELISA. The results have shown that CRP and ADA increased linearly in relation to disease phase, CRP being significantly higher in phase III and ADA at all phases. Also, CRP and ADA were positively correlated with echocardiographic parameters of cardiac remodeling and with electrocardiographic abnormalities, and negatively with ejection fraction. CRP and ADA were higher in patients with cardiothoracic index $\geq 50 \%$, while ADA was higher in patients with ventricular repolarization disturbances. Finally, CRP was positively correlated with ADA. In conclusion, ADA and CRP are prognostic markers of cardiac dysfunction and remodeling in Chagas disease.
\end{abstract}

KEYWORDS. Chagas disease; Adenosine deaminase; C-reactive protein; Prognostic markers.

\section{INTRODUCTION}

The importance of Chagas disease as a public worldwide health problem can be explained by three main reasons: 1) the high residual prevalence in Latin American endemic countries, where the number of infected individuals has been estimated to be 7,694,500 people, which represents a prevalence of $1.45 \%$; 2) the Latin American migration from endemic areas to non-endemic developed countries such as those in North America, Europe and Australia; where the prevalence of these migrant populations has been estimated from 0.6 to $25 \%$; 3 ) the re-emergence of the disease's transmission, as oral transmission outbreaks in certain Latin American countries ${ }^{16}$.

Chagas chronic cardiomyopathy is the most important consequence of Trypanosoma cruzi (T. cruzi) infection that affects $20-30 \%$ of infected people. It is considered an inflammatory cardiac disease, in which the inflammation is triggered by parasitic infection and/or by autoimmune process ${ }^{19}$. T. cruzi invades predominantly macrophages and cardiomyocytes, which generates an intense progressive multifocal inflammatory reaction, mononuclear cell infiltration and fibrosis, which lead to cardiac dysfunction. The damage and myocardium remodeling seen during Chagas disease, results from an immune imbalance in the production of pro and anti-inflammatory cytokines due to the persistence of the parasite that causes activation of inflammatory cells and a permanent inflammatory infiltrate ${ }^{9}$.

C-reactive protein (CRP), liberated during the acute phase of inflammation, is the most widely studied nonspecific marker of systemic inflammatory processes. The increased serum levels of CRP reflect a vascular inflammation state and they are associated with the development of cardiovascular events ${ }^{4}$. Increased levels of serum CRP have been reported in advanced clinical stages of Chagas cardiomyopathy ${ }^{2,18,21}$, however, this increase was similarly observed in non-chagasic cardiomyopathy ${ }^{5}$.

Adenosine (Ado) is an endogenous nucleoside, known as a cardioprotective regulator of cardiovascular function ${ }^{20}$; it has recently been implicated as a mediator of inflammation and immune response $\mathrm{e}^{17}$. Adenosine levels are regulated by the activity of the enzyme adenosine deaminase (ADA), which catalyzes the irreversible deamination of Ado. ADA activity increases as a consequence of hypoxia and inflammation associated with immunologic events ${ }^{11,24}$. T. cruzi infection causes

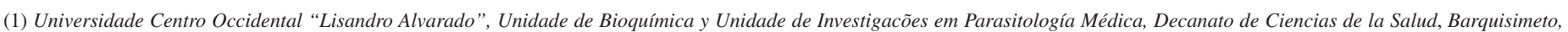
Venezuela.

(2) Ministerio del Poder Popular para la Salud, Hospital de Chabasquén, Chabasquén, Venezuela.

(3) Universidade Centro Occidental "Lisandro Alvarado”, Unidade de Investigacões em Parasitología Médica, Decanato de Ciencias de la Salud, Barquisimeto, Venezuela.

(4) Universidad de los Andes, Laboratório de Enzimologia, Facultad de Ciencias, Mérida, Venezuela.

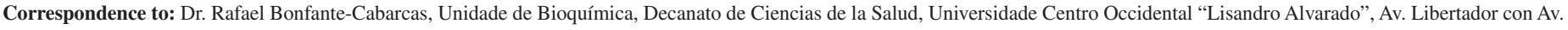
Andrés Bello, código postal 3001, Barquisimeto, Lara, Venezuela. Teléfono:+58-251-2591854. E-mail: rcabarca@ucla.edu.ve 


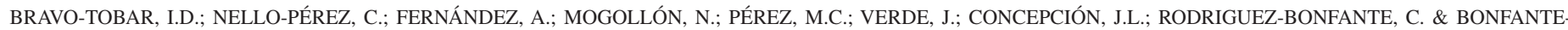
CABARCAS, R. - Adenosine deaminase activity and serum C-reactive protein as prognostic markers of Chagas disease severity. Rev. Inst. Med. Trop. Sao Paulo, 57(5): 385-92, 2015.

alterations in the coronary microvasculature, which leads to multifocal necrosis, cardiac ischemia, severe inflammation, and hipoxia ${ }^{1}$. Consequently, the degree of cardiac hypoxia and inflammation must be related to the degree of myocardial function impairment.

Because inflammation and hypoxia are important pathological events in the development of Chagasic cardiomyopathy, biochemical markers of these events could be prognostic markers of the evolution of Chagas disease. In the present study, we analyzed the relationship between serum CRP levels (as a marker of inflammation) and the serum activity of ADA (as marker of hypoxia) in relation to the clinical status of Chagas disease.

\section{METHODS}

Sample: A cross-sectional study was conducted in individuals from Unda municipality, located in the central west region of Venezuela. A sample of 110 individuals aged between seven and 91 years old were included: 82 chagasic patients and 28 healthy volunteers. Chagasic patients were classified according to the Andes classification ${ }^{7}$ as follows: Phase I, asymptomatic patients with no electrocardiographic or echocardiographic evidence of cardiac involvement; Phase II: asymptomatic patients with electrocardiographic or echocardiographic evidence of cardiac involvement; and Phase III: patients with heart failure. All participants underwent a complete medical history, physical examination, posteroanterior chest radiography, 12-lead electrocardiogram and transthoracic echocardiogram.

For this study, exclusion criteria were non-chagasic heart disease, liver disease, acute and chronic inflammatory processes, diabetes mellitus, hypertension, pneumonia, tuberculosis and consumption of illicit drugs.

The study protocol was submitted and approved by the Ethics Committee at the Health Sciences at the Universidad Centro Occidental "Lisandro Alvarado", Barquisimeto, Venezuela. All patients or their representatives understood and willingly signed the informed consent before being included in the study.

Serological diagnosis of Chagas disease: It has been based on the determination of anti-T cruzi antibodies by ELISA and MABA (multiple antigen blot assays or three-band immunoblot assay) techniques; specific recombinant antigens were used in both cases (PGR31-His, PGR24His, and PGR30-His); in ELISA as a chimeric protein and in MABA individually. These recombinant antigens represent peptide sequences encoded specifically by the $T$. cruzi genome, which allows the test to have $100 \%$ specificity. The use of three antigens allows us to achieve a higher than $95 \%$ sensitivity. The MABA was considered positive when at least two of the three recombinant antigen bands were reactive. Samples were considered positive only if both ELISA and MABA proved reactive and were considered negative if one or both tests were nonreactive ${ }^{25}$.

Determination of serum CRP levels: Serum CRP levels were measured with ELISA kit VITRO 250 (Johnson \& Johnson), according to manufacturer instructions.

Determination of ADA activity: ADA serum activity was determined spectrophotometrically using the colorimetric method described by GIUSTI \& GALANTI (1984) $)^{15}$, which is based on the indirect measurement of the formation of ammonia, using adenosine as a substrate, according to a previously validated protocol ${ }^{30,32}$.

Statistical Analysis: Results are presented as the mean \pm standard error (SEM).

Because CRP serum levels and ADA serum activity showed not to have a normal distribution, the differences observed between the experimental groups were determined by Kruskal-Wallis test, followed by Dunn's post hoc analysis. Wilcoxon test was used to analyze the observed difference between two experimental variables. A linear correlation analysis was performed using Pearson. In all cases, a $p<$ 0.05 was accepted as significant.

\section{RESULTS}

The average age for the sample was $50.33 \pm 1.58$ (95\% CI: $47.2-$ 53.45) years old, being the minimum age seven and the maximum age 91-years-old. Mean ages in years according to the group were: control $39.21 \pm 1.58$ (95\% CI: 35.97-42.46), phase I $48.4 \pm 2.76$ (95\% CI: 42.7954.01), phase II $52.9 \pm 2.88$ (95\% CI: 46.99-58.8) and phase III 67.22 \pm 3.25 (95\% CI 60.37-74.08) years old, the age of phase III patients being significantly higher when compared to the other groups, a fact that could be linked to the time necessary for the disease's development. No statistically significant difference between patients in phase I and II was observed. Of the total, 40 patients were male (nine controls, 12 in phase I, 10 in phase II and nine in phase III) and 70 female (19 controls, 23 in phase I, 19 in phase II and nine in phase III); no significant association between sex and clinical phase of the disease was observed. In Tables 1, 2 and 3 clinical (physical examination), electrocardiographic, and echocardiographic characteristics of patients are shown.

Serum levels of C-reactive protein in the sample were $1.64 \pm 0.36$ $\mathrm{mg} / \mathrm{L}(\mathrm{n}=28)$ for controls and $4.27 \pm 0.73 \mathrm{mg} / \mathrm{L}(\mathrm{n}=82)$ for chagasic patients, being the difference statistically significant $(p<0.05)$. By analyzing the values in relation to clinical stages of the disease, we observed that serum levels increased linearly and significantly, as the disease progresses to more advanced stages (see Fig. 1). Serum levels of C-reactive protein were negatively correlated with left ventricle ejection fraction, indicating that it could be a marker of ventricular function (Fig. 3). In contrast, serum levels of C-reactive protein were positively correlated with systolic and diastolic left ventricular diameter, with left ventricular mass, and left ventricular mass index; the same results were obtained regarding the diastolic diameter of the right ventricle, indicating that CRP is a marker of cardiac remodeling (Table 4 and Fig. 4). This finding was confirmed by observing that CRP levels were significantly $(p<0.05)$ higher in patients with $\geq 50 \%$ cardiothoracic index $(5.56 \pm$ 1.25 ) when compared with patients with a cardiothoracic index $<50 \%$ (2.63 \pm 0.54$)$ (Fig. 5).

Similarly, serum CRP levels were positively correlated with the frequency of different types of electrocardiographic abnormalities (Table 4), also it was observed that patients with one or more types of electrocardiographic abnormalities had significantly higher serum CRP levels when compared with patients without electrocardiographic disorders (patients with disorders: $5.43 \pm 1.12 \mathrm{mg} / \mathrm{L}$; patients without disorders: $2.03 \pm 0.37 \mathrm{mg} / \mathrm{L}, p<0.05)$.

In the present study, there were no significant differences $(p<0.05)$ in 


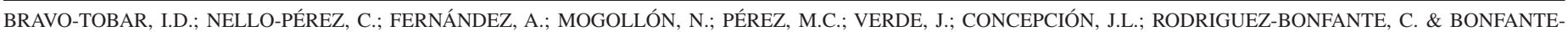
CABARCAS, R. - Adenosine deaminase activity and serum C-reactive protein as prognostic markers of Chagas disease severity. Rev. Inst. Med. Trop. Sao Paulo, 57(5): 385-92, 2015.

Table 1

Findings on physical examination in control individuals and patiens with Chagas disease

\begin{tabular}{|c|c|c|c|c|c|c|c|c|c|c|}
\hline \multirow{2}{*}{ Sigs } & \multicolumn{2}{|c|}{ CONTROL } & \multicolumn{2}{|c|}{ PHASE I } & \multicolumn{2}{|c|}{ PHASE II } & \multicolumn{2}{|c|}{ PHASE III } & \multicolumn{2}{|c|}{ TOTAL } \\
\hline & $\mathbf{n}$ & $\%$ & $\mathbf{n}$ & $\%$ & $\mathbf{n}$ & $\%$ & $\mathbf{n}$ & $\%$ & $\mathbf{n}$ & $\%$ \\
\hline JVD & 0 & 0 & 0 & 0 & 0 & 0 & 14 & 77.77 & 14 & 12.72 \\
\hline Dyspnoea & 0 & 0 & 0 & 0 & 5 & 17.24 & 13 & 72.22 & 18 & 16.36 \\
\hline Orthopnea & 0 & 0 & 0 & 0 & 0 & 0 & 2 & 11.11 & 2 & 1.81 \\
\hline Pulmonary rales & 0 & 0 & 0 & 0 & 0 & 0 & 3 & 16.66 & 3 & 2.72 \\
\hline VPA & 0 & 0 & 0 & 0 & 5 & 17.24 & 13 & 72.22 & 18 & 16.36 \\
\hline HJR & 0 & 0 & 0 & 0 & 0 & 0 & 1 & 5.55 & 1 & 0.90 \\
\hline Hepatomegaly & 0 & 0 & 0 & 0 & 0 & 0 & 2 & 11.11 & 2 & 1.81 \\
\hline Ascites & 0 & 0 & 0 & 0 & 0 & 0 & 2 & 11.11 & 2 & 1.81 \\
\hline Gallop rhythm & 0 & 0 & 0 & 0 & 0 & 0 & 3 & 16.66 & 3 & 2.72 \\
\hline ASHS & 0 & 0 & 0 & 0 & 0 & 0 & 2 & 11.11 & 2 & 1.81 \\
\hline Alternating pulse & 0 & 0 & 0 & 0 & 0 & 0 & 1 & 5.55 & 1 & 0.90 \\
\hline Bimalleolar edema & 0 & 0 & 0 & 0 & 3 & 10.34 & 17 & 94.44 & 20 & 18.18 \\
\hline
\end{tabular}

JDU: jugular venous distension; VPA: visible and palpable apex; HJR: hepatojugular reflux; ASHS: accentuated second heart sound.

Table 2

Electrocardiographic abnormalities

\begin{tabular}{lcccccccccc}
\hline \multirow{2}{*}{ ECG tracing } & \multicolumn{2}{c}{ CONTROL } & \multicolumn{2}{c}{ PHASE I } & \multicolumn{2}{c}{ PHASE II } & \multicolumn{2}{c}{ PHASE III } & \multicolumn{2}{c}{ TOTAL } \\
\cline { 2 - 10 } & $\mathbf{n}$ & $\mathbf{\%}$ & $\mathbf{n}$ & $\mathbf{\%}$ & $\mathbf{n}$ & $\mathbf{\%}$ & $\mathbf{n}$ & $\boldsymbol{\%}$ & $\mathbf{n}$ & $\mathbf{\%}$ \\
\hline No sinus rhythm & 0 & 0 & 0 & 0 & 0 & 0 & 4 & 25.00 & 4 & 3.77 \\
Sinus bradycardia & 2 & 7.69 & 0 & 0 & 5 & 17.24 & 1 & 6.25 & 8 & 7.69 \\
Sinus tachycardia & 0 & 0 & 0 & 0 & 1 & 3.44 & 0 & 0 & 1 & 0.96 \\
Atrial fibrillation & 0 & 0 & 0 & 0 & 0 & 0 & 3 & 18.75 & 3 & 2.88 \\
Ventricular extrasystole & 0 & 0 & 0 & 0 & 0 & 0 & 2 & 11.11 & 2 & 1.81 \\
AV block & 0 & 0 & 0 & 0 & 0 & 0 & 1 & 6.25 & 1 & 0.96 \\
Left anterior hemiblock & 2 & 7.69 & 0 & 0 & 14 & 48.27 & 7 & 43.75 & 23 & 22.11 \\
Left posterior hemiblock & 0 & 0 & 0 & 0 & 1 & 3.44 & 0 & 0 & 1 & 0.96 \\
Right bundle branch block & 0 & 0 & 0 & 0 & 13 & 44.82 & 3 & 18.75 & 16 & 15.38 \\
Left bundle branch block & 0 & 0 & 0 & 0 & 5 & 17.24 & 3 & 16.66 & 8 & 7.69 \\
Left ventricular enlargement & 0 & 0 & 0 & 0 & 3 & 10.34 & 1 & 6.25 & 4 & 3.84 \\
Repolarization disorders & 0 & 0 & 0 & 0 & 6 & 18.18 & 9 & 56.25 & 15 & 14.23 \\
\hline
\end{tabular}

the levels of serum CRP in patients with a medical history of hypertension compared to those patients with no hypertension history (patients with history: $5.51 \pm 0.58 \mathrm{mg} / \mathrm{L}, \mathrm{n}=18$; patients without history: $3.12 \pm 0.58$ $\mathrm{mg} / \mathrm{L}, \mathrm{n}=56$ ), as well as in patients with blood pressure values $\geq 90$ $\mathrm{mmHg}(3.26 \pm 1.31 \mathrm{mg} / \mathrm{L})$ when compared with patients with blood pressure values $<90 \mathrm{mmHg}(3.89 \pm 0.67 \mathrm{mg} / \mathrm{L})$ at physical examination.

The serum activity of the enzyme adenosine deaminase in the sample was $33.7 \pm 2.17 \mathrm{nmol} / \mathrm{mL}(\mathrm{n}=28)$ for control patients and $53.97 \pm 2.76$ $\mathrm{nmol} / \mathrm{mL}(\mathrm{n}=82)$ for chagasic patients; being the difference statistically significant $(p<0.05)$. By analyzing the values in relation to clinical stages of the disease, we observed that serum enzyme activity increased linearly and significantly as the disease was in an advanced phase (see Fig. 2); however, values of ADA were correlated with age, being higher in aged individuals; for this reason, we corrected ADA levels based on age and analyzed the results again against the clinical phase of Chagas disease, and we found similar results compared to uncorrected data, confirming that the increased levels of ADA were in fact related to the severity of the disease.

Serum ADA enzyme activity was negatively correlated with the ejection fraction of the left ventricle, also turning into a marker of ventricular function and was positively correlated with left ventricular systolic diameter, left ventricular mass, left ventricular mass index, and frequency of different types of electrocardiographic abnormalities, indicating that ADA activity is related to muscle and electrical remodeling of the heart (Table 4; Fig. 3 and 4).

This was confirmed by the fact that serum ADA activity was significantly higher $(p<0.05)$ in patients with a cardiothoracic index $\geq$ 
BRAVO-TOBAR, I.D.; NELLO-PÉREZ, C.; FERNÁNDEZ, A.; MOGOLLÓN, N.; PÉREZ, M.C.; VERDE, J.; CONCEPCIÓN, J.L.; RODRIGUEZ-BONFANTE, C. \& BONFANTECABARCAS, R. - Adenosine deaminase activity and serum C-reactive protein as prognostic markers of Chagas disease severity. Rev. Inst. Med. Trop. Sao Paulo, 57(5): 385-92, 2015.

Table 3

Echocardiographic characteristics of healthy and chagasic patients

\begin{tabular}{|c|c|c|c|c|}
\hline \multirow{3}{*}{ Parameters } & \multicolumn{4}{|c|}{ Chagasic patients } \\
\hline & CONTROL & PHASE I & PHASE II & PHASE III \\
\hline & Mean \pm SEM & Mean \pm SEM & Mean \pm SEM & Mean \pm SEM \\
\hline RVDD (mm) & $14.62 \pm 0.35$ & $13.95 \pm 0.61$ & $15.29 \pm 0.81$ & $17.71 \pm 1.76^{* \mathrm{C}, \mathrm{I}}$ \\
\hline LVEDD (mm) & $48.85 \pm 0.56$ & $49.90 \pm 1.05$ & $51.15 \pm 1.12$ & $57.37 \pm 2.84 * \mathrm{C}, \mathrm{I}, \mathrm{II}$ \\
\hline LVESD (mm) & $29.88 \pm 1.36$ & $33.85 \pm 0.76$ & $34.80 \pm 1.02$ & $41.00 \pm 3.25 * \mathrm{C}, \mathrm{I}, \mathrm{II}$ \\
\hline IVS (mm) & $8.48 \pm 0.0$ & $8.91 \pm 1.27$ & $9.48 \pm 2.41$ & $10.53 \pm 2.66 * \mathrm{C}$ \\
\hline LVT (mm) & $10.56 \pm 0.14$ & $8.82 \pm 0.42 * \mathrm{C}$ & $9.66 \pm 0.48$ & $9.90 \pm 0.65$ \\
\hline LA (mm) & $30.56 \pm 0.77$ & $26.75 \pm 1.38$ & $27.18 \pm 1.31$ & $35.55 \pm 3.11 * \mathrm{IIII}$ \\
\hline $\mathrm{EF}(\%)$ & $68.33 \pm 0.73$ & $64.85 \pm 1.12$ & $63.13 \pm 2.08$ & $53.83 \pm 3.77 * \mathrm{C}, \mathrm{I}, \mathrm{II}$ \\
\hline LVMI $\left(\mathrm{gr} / \mathrm{m}^{2} \mathrm{SC}\right)$ & $132.16 \pm 5.09$ & $173.80 \pm 6.23$ & $188.75 \pm 8.49$ & $260.72 \pm 8.88$ \\
\hline
\end{tabular}

RVDD: right ventricular diastolic diameter; LVEDD = left ventricular end diastolic diameter; LVESD = left ventricular end sistolic diameter; IVS = interventricular septum at end diastole; LVT: diastolic left ventricular posterior wall thickness; LA: diastolic diameter of the left atrium; EJ: ejection fraction; LVMI: left ventricular mass index. *means $p<0.05$ as compared with C (Control), I (Phase I) or II (Phase II) using ANOVA followed by Bonferroni post test.
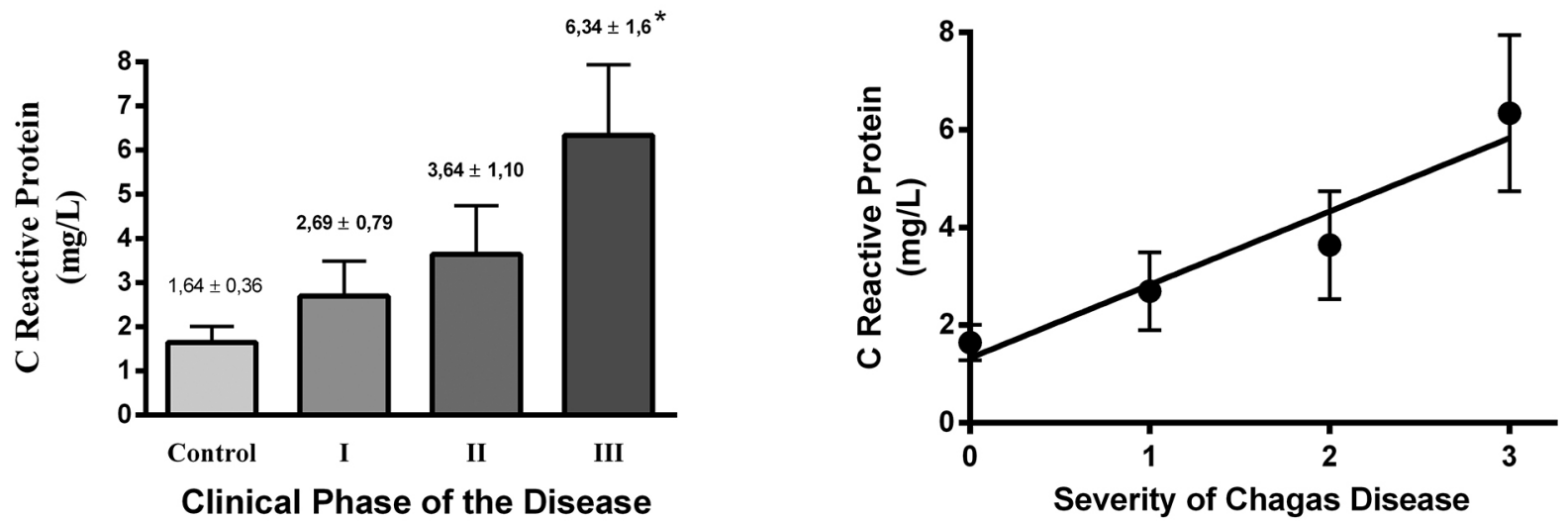

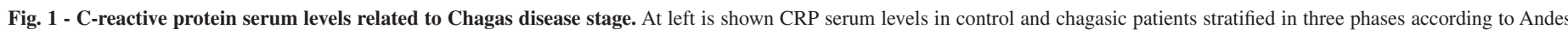

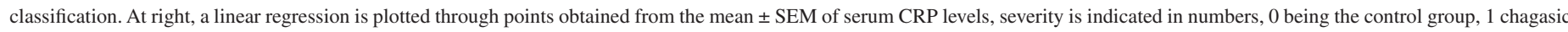

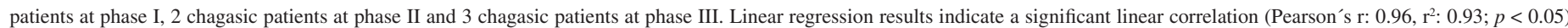
between CRP serum levels and severity of the Chagas disease. * means $p<0.05$ as compared with control patients.

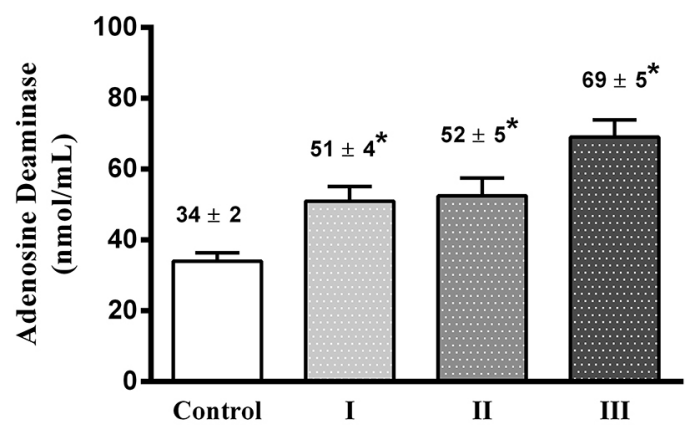

Clinical Phase of the Disease

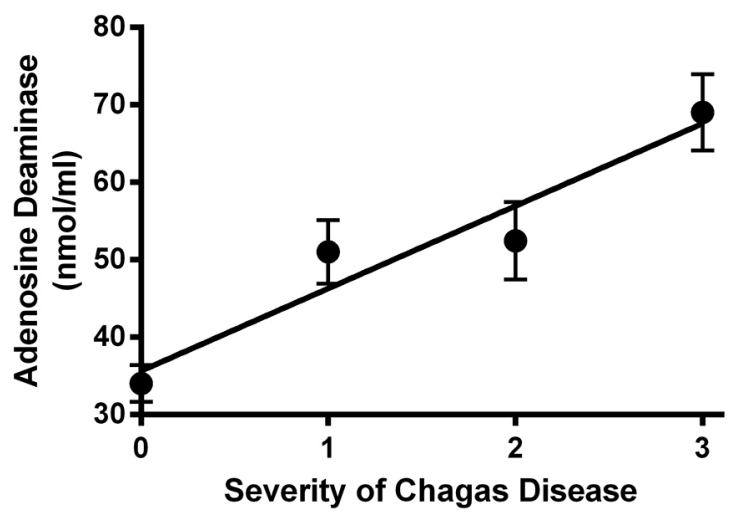

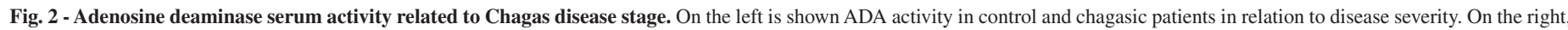

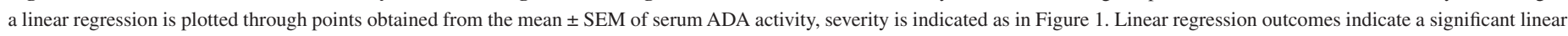
correlation (Pearson's r: 0.96, r2: 0.92; $p<0.05$ ) between CRP serum levels and severity of the Chagas disease. *means $p<0.05$ as compared with control patients. 

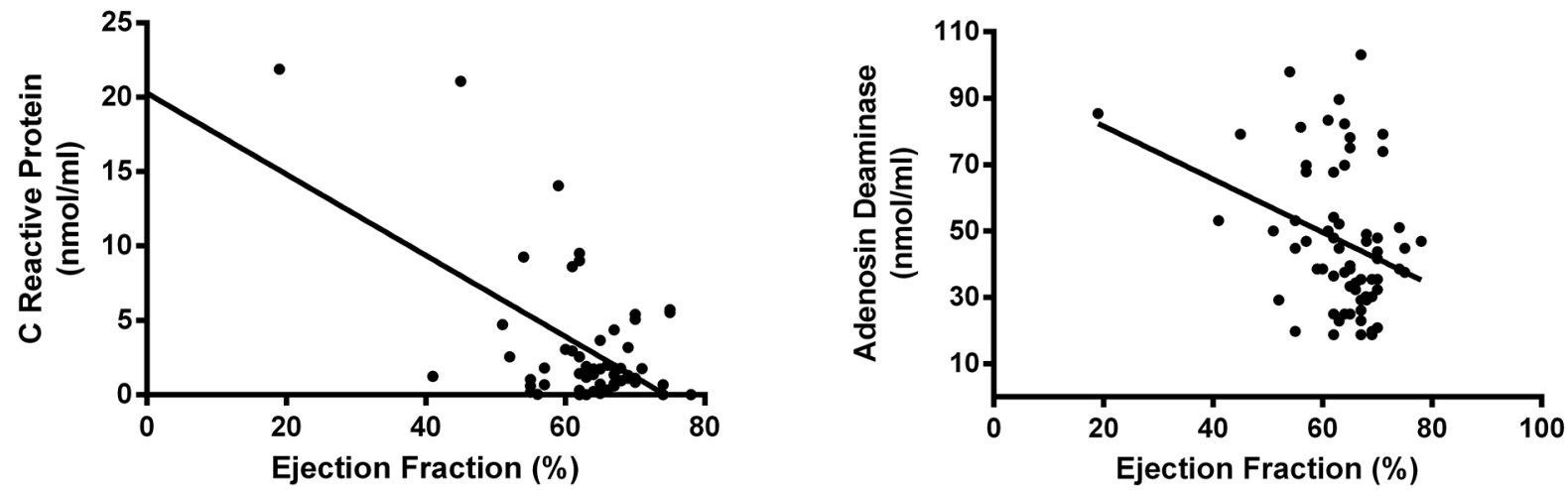

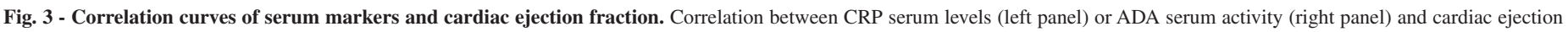
fraction are shown. Results are displayed in Table IV.

Table 4

Correlation analysis between serum levels of C-reactive protein or adenosine deaminase serum enzyme activity in relation to echocardiographic and electrocardiographic parameters

\begin{tabular}{|c|c|c|c|c|c|c|c|c|}
\hline \multirow{2}{*}{ Parameter } & \multicolumn{4}{|c|}{ CRP } & \multicolumn{4}{|c|}{ ADA } \\
\hline & Pearson $\mathbf{r}$ & IC95\% & $\mathbf{R}^{2}$ & $p$ & Pearson $\mathbf{r}$ & IC95\% & $\mathbf{R}^{2}$ & $p$ \\
\hline $\mathrm{EF}$ & -0.55 & $-0.72-(-0.34)$ & 0.31 & $<0.01$ & -0.33 & $-0.52-(-0.09)$ & 0.11 & 0.01 \\
\hline RVDD & 0.63 & $0.37-0.8$ & 0.4 & $<0.01$ & 0.17 & $-0.14-0.46$ & 0.03 & 0.28 \\
\hline LVEDD & 0.27 & $0.02-0.5$ & 0.08 & 0.04 & 0.22 & $-0.02-0.44$ & 0.05 & 0.07 \\
\hline LVESD & 0.42 & $0.17-0.62$ & 0.18 & $<0.01$ & 0.29 & $0.05-0.50$ & 0.08 & 0.02 \\
\hline IVS & 0.26 & $-0.01-0.49$ & 0.07 & 0.06 & 0.12 & $-0.12-0.35$ & 0.02 & 0.32 \\
\hline LVT & $<-0.01$ & $-0.27-0.27$ & $<0.01$ & 0.98 & 0.01 & $-0.23-0.25$ & $<0.01$ & 0.93 \\
\hline LA & 0.38 & $0.12-0.58$ & 0.14 & 0.01 & 0.22 & $-0.03-0.44$ & 0.05 & 0.08 \\
\hline LVM & 0.39 & $0.15-0.60$ & 0.16 & $<0.01$ & 0.26 & $0.02-0.47$ & 0.07 & 0.03 \\
\hline LVMI & 0.39 & $0.13-0.60$ & 0.15 & $<0.01$ & 0.36 & $0.13-0.56$ & 0.13 & $<0.01$ \\
\hline ECG abnormalities & 0.33 & $0.11-0.52$ & 0.11 & $<0.01$ & 0.33 & $0.13-0.51$ & 0.11 & $<0.01$ \\
\hline
\end{tabular}

RVDD: right ventricular diastolic diameter; LVEDD = left ventricular end diastolic diameter; LVESD = left ventricular end sistolic diameter; IVS = interventricular septum at end diastole; LVT: diastolic left ventricular posterior wall thickness; LA: diastolic diameter of the left atrium; EJ: ejection fraction; LVMI: left ventricular mass index. Data was obtained by Pearson correlation.
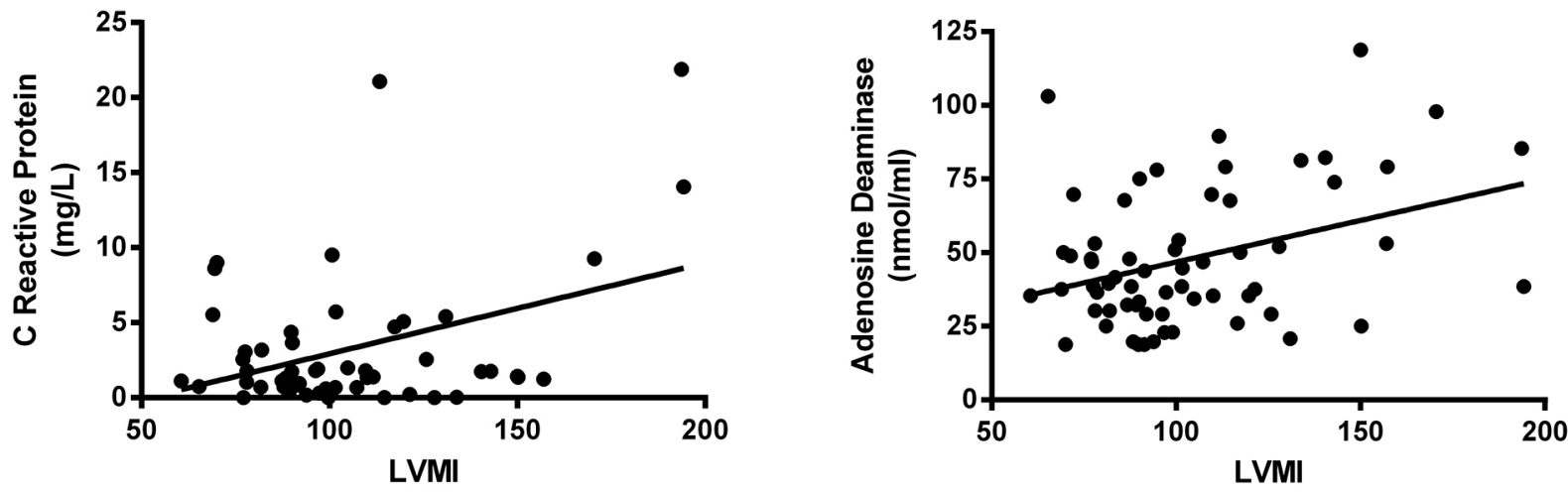

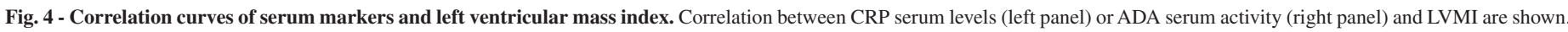
Results are displayed in Table IV. 


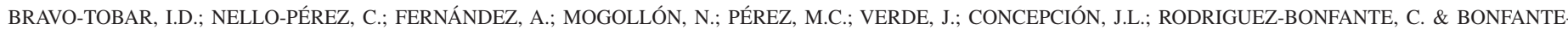
CABARCAS, R. - Adenosine deaminase activity and serum C-reactive protein as prognostic markers of Chagas disease severity. Rev. Inst. Med. Trop. Sao Paulo, 57(5): 385-92, 2015.
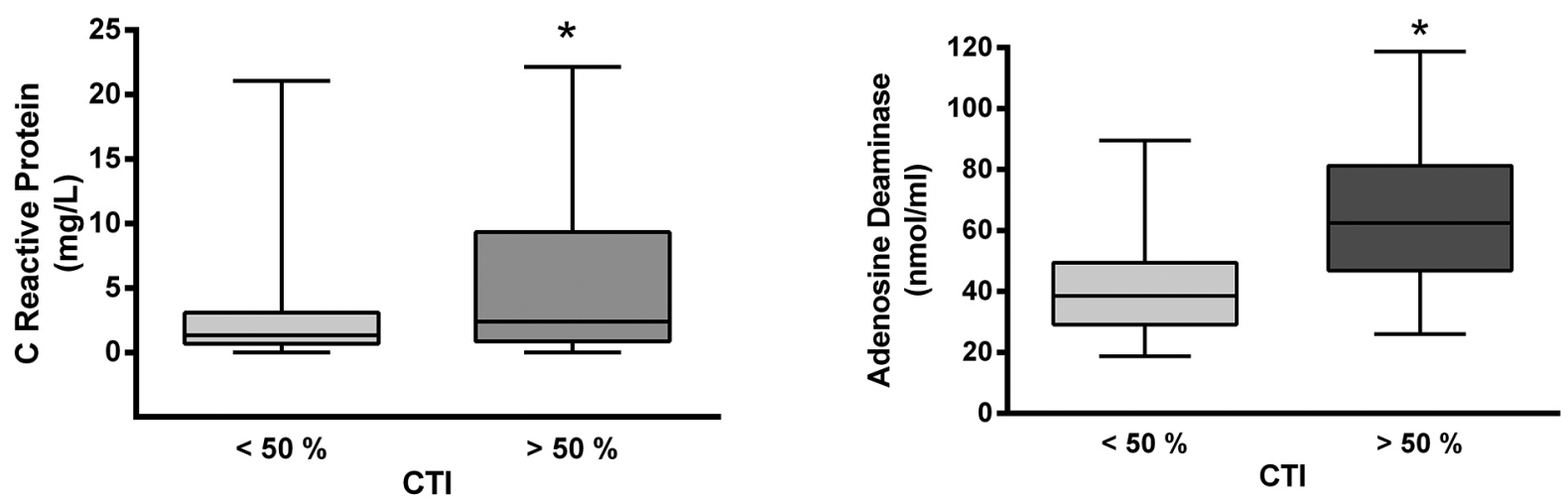

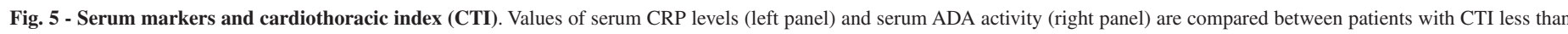
$50 \%$ and patients with CTI higher than $50 \%$. Observe that in both cases the levels of serum markers are significantly $(* p<0.05)$ elevated in patients with CTI $>50 \%$.

$50 \%(64.65 \pm 4.319 \mathrm{nmol} / \mathrm{mL})($ Fig. 5) and in patients with ventricular repolarization disturbances $(72.70 \pm 9.46 \mathrm{nmol} / \mathrm{mL})$, when compared with patients with cardiothoracic index $<50 \%(42.69 \pm 2.43 \mathrm{nmol} / \mathrm{mL})$ and in patients without repolarization disturbances $(47.28 \pm 2.4 \mathrm{nmol} /$ $\mathrm{mL})$, respectively.

Given the fact that results for repolarization disorders could just reflect the phase of the disease, and since control and phase I patients did not display this abnormality, we decided to compare ADA activity in phases II and III patients, confirming that ADA activity is significantly higher in patients with impaired ventricular repolarization (with disorders: $65.88 \pm 7.26 \mathrm{nmol} / \mathrm{mL}$; without disorders: $48.61 \pm 4.51 \mathrm{nmol} / \mathrm{mL}, p<$ $0.05)$.

No significant differences in ADA serum activity in patients with a medical history of hypertension compared to patients with no history were observed (patients with history: $52.60 \pm 4.30 \mathrm{nmol} / \mathrm{mL}, \mathrm{n}=22$; patients without history: $49.21 \pm 2.90 \mathrm{nmol} / \mathrm{mL}$ ); similarly in patients with diastolic blood pressure values $\geq 90 \mathrm{mmHg}(53.17 \pm 5.16 \mathrm{nmol} / \mathrm{mL}$; $\mathrm{n}=21$ ) when compared with patients with diastolic blood pressure values $<90 \mathrm{mmHg}(49.08 \pm 2.75 \mathrm{nmol} / \mathrm{mL} ; \mathrm{n}=67)$ at physical examination. Finally, serum ADA activity was positively correlated with serum CRP levels (Pearson's r: 0.24, 95\%CI 0.01-0.44, $\mathrm{r}^{2} 0.06$ and $p<0.05$ ) (Table 4).

\section{DISCUSSION}

CRP, among other systemic inflammatory mediators, has been widely accepted as a potent risk indicator, independently predicting future cardiovascular events. The impact of CRP on cardiovascular outcome has been corroborated by a large number of observational studies and meta-analyses. These studies show that an elevated CRP has a clear prognostic value for major cardiovascular events and mortality, whereas the lowering of CRP is associated with a reduction in cardiovascular risk ${ }^{4}$.

In the present paper, we confirmed that CRP is a sensitive marker for the evolution of Chagas disease, especially at later stages related to the presence of heart failure (phase III). In this sense, it has been found that serum CRP levels only increase in the most advanced phase of the disease, indicating that CRP serum levels could be of prognostic value in assessing Chagas disease progression ${ }^{2,18,21}$.
Similarly, it has been found that CRP is significantly higher in patients with chagasic cardiomyopathy than in healthy subjects or asymptomatic chagasic subjects ${ }^{10,26}$.

However, CRP is a nonspecific marker of inflammation that noticeably rises in advanced stages of heart disease, disregarding the etiology. This was demonstrated by BRAVO et al. $(2010)^{5}$, who reported that CRP levels are elevated in patients with decompensated heart failure. They found no statistically significant differences between patients with serum antibodies for T. cruzi and seronegative patients, notwithstanding, they found that CRP levels were significantly higher in patients in class IV of New York Heart Association functional classification (NYHA IV) when compared with patients in NYHA III, indicating that the CRP serum levels are associated with the severity of the cardiac pathology.

In the present paper, CRP levels were significantly correlated with echocardiographic parameters of cardiac remodeling and ejection fraction. In this regard, it has been demonstrated that patients with acute myocardial infarction and higher plasma CRP levels are more prone to developing left ventricular dysfunction and remodeling ${ }^{12,27}$, and to have alterations in left ventricular geometry in patients with essential hypertension $^{31}$.

We also observed that serum levels of CRP were correlated with electrocardiographic disturbances; in this respect, it has been observed that high serum levels of CRP are significantly associated with the occurrence of ventricular tachycardia, and/or atrial or ventricular fibrillation in patients with ischemia ${ }^{3,8}$.

The other biochemical marker used in the present study was ADA. We have found that its serum activity had a similar behavior to CRP, including a linear correlation between them. In addition, serum activity was significantly higher in seropositive patients and there was a linear trend to increase with the clinical phase of the disease. These results are different from those reported by previous studies in patients with Chagas disease $^{6,28,29}$. Although one could argue that the differences observed in the present study, with respect to the previous reports are due to the sample type and the absence of healthy controls to compare the values obtained in chagasic patients; it is more prudent to analyze the results in an appropriate pathogenic context. 
BRAVO-TOBAR, I.D.; NELLO-PÉREZ, C.; FERNÁNDEZ, A.; MOGOLLÓN, N.; PÉREZ, M.C.; VERDE, J.; CONCEPCIÓN, J.L.; RODRIGUEZ-BONFANTE, C. \& BONFANTECABARCAS, R. - Adenosine deaminase activity and serum C-reactive protein as prognostic markers of Chagas disease severity. Rev. Inst. Med. Trop. Sao Paulo, 57(5): 385-92, 2015.

It has been clearly shown that ADA is a marker of hypoxia and inflammation. During hypoxia, ADA expression is increased due to a compensatory mechanism as a result of elevated levels of adenosine ${ }^{11}$. Plasma adenosine levels' increase in patients with ischemic and nonischemic heart failure, and the extent of this increment correlates with the severity of the disease $\mathrm{e}^{13,14}$, demonstrating the indisputable fact that during heart failure there is hypoxia, that therefore stimulates ADA expression. TORRELLAS et al. $(2010)^{31}$ demonstrated that serum ADA activity increase in patients with acute myocardial infarction and in the present paper we have also demonstrated that serum ADA activity is associated with repolarization disturbances.

On the other hand, ADA (as a marker of inflammation) has been implicated as a result of the inflammation-induced hypoxia and with the change in protein expression product of its RNA editing activity ${ }^{33}$, which may affect the inflammatory and immune response through modulation of protein synthesis ${ }^{33,34}$. Moreover, ecto-ADA, an isoenzyme anchored to the surface of dendritic cells through $\mathrm{A} 2 \mathrm{~B}$ adenosine receptor, binds to the CD26 protein expressed on the surface of $\mathrm{T}$ cells as part of the immunological synapse and provides a co-stimulatory signal that increases activation of T cells and their polarization to a Th1 phenotype ${ }^{23}$.

Also ADA, like CRP, was correlated with echocardiographic parameters of cardiac remodeling. This finding could be related to ADA overexpression, which increases adenosine catabolism preventing its inhibitory effect on promoting synthesis of collagen and proteins in fibroblasts and cardiomyocytes ${ }^{22}$.

Finally, our results suggest that inflammation increases as Chagas disease reaches advanced phases, which is related to the CRP blood levels and cardiac dysfunction. This creates a theoretical support to claim that ADA activity is increased in Chagas disease and should increase even more as far as the disease worsens, which is reflected in our results. Even more, we showed that serum ADA activity correlates with serum levels of $\mathrm{CRP}$, corroborating the idea that ADA is also a marker of inflammation and impaired cardiac function related to hypoxia.

\section{RESUMO}

\section{Atividade da adenosina deaminase e níveis de proteina $\mathrm{C}$ reativa sérica como marcadores de gravidade na doença de Chagas}

Introdução e objetivo. A Doença de Chagas é um problema de saúde pública mundial. A disponibilidade de ferramentas diagnósticas para prever o desenvolvimento de miocardiopatia chagásica crônica é fundamental para reduzir a morbidade e a mortalidade. Aqui estudamos o valor prognóstico da atividade sérica da adenosina deaminase (ADA) e dos níveis de proteína $\mathrm{C}$ reativa (PCR) em indivíduos chagásicos. Métodos: 110 indivíduos: 28 saudáveis e 82 pacientes chagásicos foram divididos de acordo com a gravidade da doença em fase I $(n=35)$, II $(\mathrm{n}=29)$ e III $(\mathrm{n}=18)$. Para cada indivíduo foram feitos uma história médica, eletrocardiograma, radiografia de tórax e ecocardiografía transtorácica. O diagnóstico de Chagas foi confirmado por ELISA e MABA utilizando antígenos recombinantes, a atividade sérica da enzima ADA foi determinada por espectrofotometria, e os níveis séricos de PCR por ELISA. Resultados: os níveis de PCR e da atividade da ADA aumentaram linearmente em relação à fase da doença, sendo a PCR significativamente maior na fase III, e a ADA em todas as fases.
Além disso, PCR e ADA foram correlacionados positivamente com parâmetros ecocardiográficos de remodelamento cardíaco e alterações eletrocardiográficas, e negativamente com a fração de ejeção. PCR e ADA foram mais elevadas em pacientes com índice cardiotorácico $\geq 50 \%$, enquanto que a ADA foi maior em pacientes com alterações da repolarização ventricular. Finalmente, os níveis de PCR foram correlacionados positivamente com a atividade da ADA. Conclusão: ADA e PCR são marcadores prognósticos de disfunção e remodelamento cardíaco na Doença de Chagas, e devem ser incluídos na avaliação e acompanhamento dos pacientes.

\section{ACKNOWLEDGMENTS}

This study was funded by the National Fund for Science and Technology (FONACIT) under the Ministry of Popular Power for Science and Technology (Venezuela), Project No 2007001425.

\section{AUTHOR CONTRIBUTIONS}

I. D. Bravo-Tobar was responsible for sample collection, experimental procedures and writing the manuscript; C. Nello-Pérez was responsible for sample collection, experimental procedures and collaborated in study design; A. Fernández was responsible for sample collection and collaborated in study design; N. Mogollón was responsible for sample collection and experimental procedures; M.C. Pérez was responsible for experimental procedures; J. Verde was responsible for experimental procedures; J.L. Concepción was responsible for experimental procedures and collaborated in study design; C. Rodríguez-Bonfante collaborated in study design; R. Bonfante-Cabarcas was responsible for the study design, and collaborated in the experimental procedures and writing the manuscript.

\section{REFERENCES}

1. Alvarado-Tapias E, Miranda-Pacheco R, Rodríguez-Bonfante C, Velásquez G, Loyo J, GilOviedo $\mathrm{M}$, et al. Electrocardiography repolarization abnormalities are characteristic signs of acute chagasic cardiomyopathy. Invest Clin. 2012;53:378-94.

2. Aparecida da Silva C, Fattori A, Sousa AL, Mazon SB, Monte Alegre S, Almeida EA, et al. Determining the C-reactive protein level in patients with different clinical forms of Chagas disease. Rev Esp Cardiol. 2010;63:1096-9.

3. Biasucci LM, Giubilato G, Biondi-Zoccai G, Sanna T, Liuzzo G, Piro M, et al. C reactive protein is associated with malignant ventricular arrhythmias in patients with ischaemia with implantable cardioverter-defibrillator. Heart. 2006;92:1147-8.

4. Bisoendial RJ, Boekholdt SM, Vergeer M, Stroes ES, Kastelein JJ. C-reactive protein is a mediator of cardiovascular disease. Eur Heart J. 2010;31:2087-91.

5. Bravo Tobar I, Parra F, Nello Pérez C, Rodríguez-Bonfante C, Useche F, BonfanteCabarcas R. Prevalence of Trypanosoma cruzi antibodies and inflammatory markers in uncompensated heart failure. Rev Soc Bras Med Trop. 2011;44:691-6.

6. Budni P, Pedrosa RC, Dalmarco EM, Dalmarco JB, Frode TS, Wilhelm Filho D. Carvedilol enhances the antioxidant effect of vitamins $\mathrm{E}$ and $\mathrm{C}$ in chronic Chagas heart disease. Arq Bras Cardiol. 2013;101:304-10.

7. Carrasco HA, Parada H, Guerrero L, Duque M, Durán D, Molina C. Prognostic implications of clinical, electrocardiographic and hemodynamic findings in chronic Chagas' disease. Int J Cardiol. 1994;43:27-38. 
BRAVO-TOBAR, I.D.; NELLO-PÉREZ, C.; FERNÁNDEZ, A.; MOGOLLÓN, N.; PÉREZ, M.C.; VERDE, J.; CONCEPCIÓN, J.L.; RODRIGUEZ-BONFANTE, C. \& BONFANTECABARCAS, R. - Adenosine deaminase activity and serum C-reactive protein as prognostic markers of Chagas disease severity. Rev. Inst. Med. Trop. Sao Paulo, 57(5): 385-92, 2015.

8. Chung MK, Martin DO, Sprecher D, Wazni O, Kanderian A, Carnes CA, et al. C-reactive protein elevation in patients with atrial arrhythmias: inflammatory mechanisms and persistence of atrial fibrillation. Circulation. 2001;104:2886-91.

9. Cunha-Neto E, Nogueira LG, Teixeira PC, Ramasawmy R, Drigo SA, Goldberg AC, et al. Immunological and non-immunological effects of cytokines and chemokines in the pathogenesis of chronic Chagas disease cardiomyopathy. Mem Inst Oswaldo Cruz. 2009;104(Suppl 1):252-8

10. Cutrullis RA, Petray PB, Schapachnik E, Sánchez R, Postan M, González MN, et al. Elevated serum levels of macrophage migration inhibitory factor are associated with progressive chronic cardiomyopathy in patients with Chagas disease. PLOS ONE. 2013;8:e57181.

11. Eltzschig HK, Faigle M, Knapp S, Karhausen J, Ibla J, Rosenberger P, et al. Endothelial catabolism of extracellular adenosine during hypoxia: the role of surface adenosine deaminase and CD26. Blood. 2006;108:1602-10.

12. Fertin M, Hennache B, Hamon M, Ennezat PV, Biausque F, Elkohen M, et al. Usefulness of serial assessment of B-type natriuretic peptide, troponin I, and C-reactive protein to predict left ventricular remodeling after acute myocardial infarction (from the REVE-2 study). Am J Cardiol. 2010;106:1410-6.

13. Franceschi F, Deharo JC, Giorgi R, By Y, Monserrat C, Condo J, et al. Peripheral plasma adenosine release in patients with chronic heart failure. Heart. 2009;95:651-5.

14. Funaya H, Kitakaze M, Node K, Minamino T, Komamura K, Hori M. Plasma adenosine levels increase in patients with chronic heart failure. Circulation. 1997;95:1363-5.

15. Giusti G, Galanti B. Colorimetric method: adenosine deaminase. In: Bergmeyer HU, editor. Methods of enzymatic analysis. $3^{\text {rd }}$ ed. Weinheim: Verlag Chemie; 1984. p. 315-23.

16. Labrador-Hernández M, Jiménez L, Leon G, López R, Mendoza W, Bonfante-Rodriguez $\mathrm{C}$, et al. A decreased expression and functionality of muscarinic cholinergic receptor in acute Chagas myocarditis. World J Cardiovasc Dis. 2014;4:305-15.

17. Linden J. New insights into the regulation of inflammation by adenosine. J Clin Invest. 2006;116:1835-7.

18. López L, Arai K, Giménez E, Jiménez M, Pascuzo C, Rodríguez-Bonfante C, et al. $\mathrm{C}$-reactive protein and interleukin-6 serum levels increase as Chagas disease progresses towards cardiac failure. Rev Esp Cardiol. 2006;59:50-6.

19. Machado FS, Tyler KM, Brant F, Esper L, Teixeira MM, Tanowitz HB. Pathogenesis of Chagas disease: time to move on. Front Biosci (Elite Ed). 2012;4:1743-58.

20. McIntosh VJ, Lasley RD. Adenosine receptor-mediated cardioprotection: are all 4 subtypes required or redundant? J Cardiovasc Pharmacol Ther. 2012;17:21-33.

21. Melo Coutinho CM, Cavalcanti GH, Bonaldo MC, Mortensen RF, Araújo-Jorge TC. Trypanosoma cruzi: detection of a surface antigen cross-reactive to human C-reactive protein. Exp Parasitol. 1998;90:143-53.
22. Nagai T, Anzai T, Kaneko H, Mano Y, Anzai A, Maekawa Y, et al. C-reactive protein overexpression exacerbates pressure overload-induced cardiac remodeling through enhanced inflammatory response. Hypertension. 2011;57:208-15.

23. Pérez-Aguilar MC, Goncalves L, Ibarra A, Bonfante-Cabarcas R. Adenosin deaminasa como molécula coestimuladora y marcador de inmunidad celular. Invest Clin. 2010;51:561-71.

24. Rabinovici R, Kabir K, Chen M, Su Y, Zhang D, Luo X, et al. ADAR1 is involved in the development of microvascular lung injury. Circ Res. 2001;88:1066-71.

25. Rojas ME, Várquez P, Villarreal MF, Velandia C, Vergara L, Morán-Borges $\mathrm{YH}$, et al. Estudio seroepidemiológico y entomológico sobre la enfermedad de Chagas en un área infestada por Triatoma maculata (Erichson 1848) en el centro-occidente de Venezuela. Cad Saude Publica. 2008;24:2323-33.

26. Saravia SG, Haberland A, Bartel S, Araujo R, Valda G, Reynaga DD, et al. Cardiac troponin $\mathrm{T}$ measured with a highly sensitive assay for diagnosis and monitoring of heart injury in chronic Chagas disease. Arch Pathol Lab Med. 2011;135:243-8.

27. Schoos MM, Munthe-Fog L, Skjoedt MO, Ripa RS, Lønborg J, Kastrup J, et al Association between lectin complement pathway initiators, C-reactive protein and left ventricular remodeling in myocardial infarction-a magnetic resonance study. Mol Immunol. 2013;54:408-14.

28. Souza V do C, Schlemmer KB, Noal CB, Jaques JA, Zimmermann CE, Leal CA, et al. E-NTPDase and E-ADA activities are altered in lymphocytes of patients with indeterminate form of Chagas' disease. Parasitol Int. 2012;61:690-6.

29. Souza V do C, Schlemmer KB, Noal CB, Jaques JA, Bagatini MD, Pimentel VC, et al Purinergic system ecto-enzymes participate in the thromboregulation of patients with indeterminate form of Chagas disease. Purinergic Signal. 2012;8:753-62.

30. Takahashi T, Anzai T, Kaneko H, Mano Y, Anzai A, Nagai T, et al. Increased C-reactive protein expression exacerbates left ventricular dysfunction and remodeling after myocardial infarction. Am J Physiol Heart Circ Physiol. 2010;299:H1795-804.

31. Torrellas Y; Pérez-Aguilar MC, Ramos B; Useche AF; Ibarra A; Bonfante-Cabarcas R, et $a l$. Increased adenosine deaminase serum activity in patients with acute myocardial infarction. Rev Latinoam Hipertens. 2010;5:38-42.

32. Vilchez D, Pérez-Aguilar MC, Saba S, Bonfante-Cabarcas R. Los niveles séricos de adenosin deaminasa y ácido úrico se correlacionan en pacientes gestantes con trastornos hipertensivos. Rev Chil Obstet Ginecol. 2009;74:217-24.

33. Yang JH, Luo X, Nie Y, Su Y, Zhao Q, Kabir K, et al. Widespread inosine-containing mRNA in lymphocytes regulated by ADAR1 in response to inflammation. Immunology. 2003;109:15-23.

34. Yang JH, Nie Y, Zhao Q, Su Y, Pypaert M, Su H, et al. Intracellular localization of differentially regulated RNA-specific adenosine deaminase isoforms in inflammation. J Biol Chem. 2003;278:45833-42.

Received: 7 August 2014

Accepted: 24 February 2015 